\title{
UNSUR-UNSUR ISYARY DALAM SEBUAH TAFSIR NUSANTARA: Telaah Analitis Tafsir Faid al-Rahman Karya Kiai Sholeh Darat
}

\author{
Lilik Faiqoh \\ Universitas Islam Negeri (UIN) Sunan Kalijaga Yogyakarta. \\ Email: lilikfaiqoh11̄gmail.com
}

\begin{abstract}
This research discusses about the elements of isyary in a Tafsir Nusantara: Analitical study of Tafsir Faid al-Rahman created by Kiai Sholeh Darat. Kiai Sholeh Darat is a figure of ulama' tasawuf who emerged in the end of 19th century that made tafsir creation which used Javanese lamguage (Arabic pegon). Seem that there is isyary nuance when interpreting al-Qur'an verse. The elements of isyary in interpretation can enrich the treasure of Tafsir Nusantara. In this research, there are three important problems related on the theme above, the first is the elements of isyary in Kiai Sholeh Darat's interpretation. The second is which are the examples of isyary's elements that is included in tafsir Faid al-Rahman. And the third, what is the contribution and the relevance in treasure of tafsir Nusantara. With using historical approach and the methodology of tafsir, it will be explained that in a creation of tafsir Nusantara has nuance of isyary's elements when Kiai Sholeh Darat interpreted al-Qur'an verses. Exactly, this interpretation can't be separated from his own mufasir that has influence of the characters of sufi in his writings. So, this research can be concluded, the first in interpreting there are the elements of isyary, it seems when interpreting al-Qur'an verse with the nuance of isyary or sufi. The second, displayed the examples with nuance of isyary and socio-cultural, for the example about damage of earth, faith,
\end{abstract}


and praying. The third, the contribution can give riches of color or tafsir style and the solution included when there are social problems in archipelago, like there is road repairing, opening the job, and so on.

\begin{abstract}
Abstrak : Penelitian ini membahas tentang unsur-unsur isyary dalam sebuah tafsir Nusantara: Telaah analistis Tafsir Faid al-Rahman karya Kiai Sholeh Darat. Kiai Sholeh Darat merupakan tokoh ulama' tasawuf yang muncul akhir abad 19 yang melahirkan karya tafsir dengan menggunakan bahasa Jawa (Arab pegon). Terlihat sangat kentara terdapat nuansa isyary ketika menafsirkan ayat al-Qur'an. Unsur isyary dalam penafsirannya dapat memperkaya khazanah tafsir Nusantara. Dalam penelitian ini ada tiga permasalahan penting terkait tema di atas, pertama, adakah unsur-unsur isyary dalam penafsiran Kiai Sholeh Darat. Kedua, manakah contohcontoh unsur-unsur isyary yang terdapat dalam tafsir Faid alRahman. Dan ketiga, apa kontribusi dan relevansinya dalam khazanah tafsir Nusantara. Denganmenggunakan pendekatan historis dan metodologi tafsir akan dijelaskan bahwa dalam sebuah karya tafsir Nusantara ini memiliki nuansa unsurunsur isyary ketika Kiai Sholeh Darat menafsirkan ayat-ayat al-Qur'an. Tentunya penafsiran ini tidak lepas darimufasirnya sendiri yang memiliki keterpengaruhan tokoh-tokoh tasawuf dalam karya-karya tulisannya. Maka dari penelitian ini dapat disimpulkan, Pertama, di dalam penafsirannya terdapat unsur-unsur isyary, hal ini nampak ketika menafsirkan ayat al-Qur'an dengan nuansa tasawufnya atau sufi. Kedua, ditampilkan contoh-contohnya dengan nuansa isyary dan sosio-kultural, misalnya tentang kerusakan bumi, iman, dan sholat. Ketiga, kontribusinya bisa memberikan kekayaan warna atau corak tafsir dan solusi terkait ketika ada problemproblem sosial di Nusantara, seperti, adanya perbaikan jalan raya, membuka lapangan pekerjaan, dan lain-lainnya.
\end{abstract}

Keywords: Isyary, Faid al-Rahman, Tafsir Nusantara, Kiai Sholeh Darat. 


\section{A. Pendahuluan}

Perkembangan penafsiran terhadap al-Qur'an tidak hanya terjadi di dunia Arab saja, melainkan di Indonesiapun demikian. Proses kreatifitas penulis tafsir terus berkembang. Salah satu warisan intelektual Islam di Jawa pramodernisme yang perlumendapat apresiasi adalah buah karya Syaikh Muhammad Shalih ibn Umar al-Samarani, yang di kalangan Kiai di Jawa lebih dikenal dengan sebutan «Kiai Sholeh Darat». Beliau hidup semasa dengan Kiai Nawawi Banten, yakni hidup ant ara (1820-1903), sementara Kiai Nawawi Banten hidup antara (1813-1897). Keduanya memang pernah hidup berteman ketika sama-sama di Makkah, bahkan beberapa guru mereka juga sama. Keduanya juga sama-sama mempunyai karya dalam bidang Tafsir. Kiai Nawawi Banten mengarang kitab Tafsir Marah Labib li Kasf alMa'ani al-Qur'an al-Majid atau lebih dikenal dengan sebutan Tafsir al-Munir (1887-1305 H). Sedangkan Kiai Sholeh Darat mengarang kitab Tafsir Faid al-Rahman dalam bahasa Jawa, (Arab Pegon)1894$1312 \mathrm{H}){ }^{1}$

Telah banyak karya tafsir yang ditulis ulama' Indonesia, sebagian besar bertujuan dalam rangka mengisi kebutuhan literatur untuk zamannya. Khususnya tafsir yang ditulis bahasa Jawa dalam huruf (Arab pegon) atau aksara Latin, yang banyak memberikan kontribusi bagi para pembaca dari kalangan penutur bahasa Jawa. Sebagai contohnya adalah tafsir al-Huda (bahasa Jawa) ditulis oleh Bakri Syahid (w.1994), dan Tafsir Jalalen Bahasa Jawi Alus disusun oleh Bagus Arafah dalam huruf Arab (1913), ${ }^{2}$ kitab Tafsir al-Ibriz bahasa Jawa (Arab Pegon) (1980-an) ditulis KH. Bisri Mustafa dari Rembang, dan kitab tafsir Al-Iklil fi Ma'ani Tanzil bahasa Jawa (Arab Pegon) (1981-an) ditulis oleh KH. Misbahbin Zaenul Musthafa dari

1 M. Masrur, Kyai Sholeh Darat, Tafsir Faid al-Rahman dan RA. Kartini, jurnal At-Taqaddum, Vol. 4, No. 1, Juli 2012, 29.

2 Muhammad Nur Kholis Setiawan, Tafsir al-Qur'an dalam konteks keIndonesiaan dengan pola pendekatan Tematik Kombinatif, Buku Pidato pengukuhan Guru Besar UIN-Suka 2012, 18. 
Bangilan. ${ }^{3}$ Termasuk Tafsir Faid al-Rahman yang ditulis dengan bahasa Jawa (Arab Pegon) (1892-an) oleh Kiai Sholeh Darat, Semarang. ${ }^{4}$

Dalam menafsirkan al-Qur'an setiap mufassir pasti berbedabeda sesuai dengan sosio-kultural dan intelektual atau keilmuannya. Tafsir Faid al-Rahman karya Kiai Sholeh Darat al-samarani ini memiliki unsur-unsur penafsiran yang bernuansa dengan corak isyary. Tafsir isyary yakni menakwilkan ayat-ayat al-Qur'an, yang berbeda dengan dzahirnya berdasarkan isyarat-isyarat yang tersembunyi, yang hanya tampak jelas oleh orang-orang yang cerdas atau (makna batin yang lebih sebagai ta'wil lebih luas, bukan pemaknaan kata secara lahiriah, yang lebih kepada simbol-simbol). Menurut Quraish Shihab tafsir isyary merupakan makna-makna yang terdapat dari ayat-ayat alQur' an yang tidak didapatkan dari bunyi lafadz ayat, tetapi dari unsurunsur yang ditimbulkan oleh lafadz tersebut dalam benak mufassirnya yang memiliki kecerahan hati dan pikiran tanpa mempengaruhi makna lafazhnya. Tafsir isyary bisa disebut juga dengan tafsir shufy, karena biasanya banyak dilahirkan oleh para pengamal tasawuf yang memiliki kebersihan hati dan ketulusan. Dalam artikel ini penulis tertarik untuk mengkaji, bagaimana unsur-unsur isyary dalam penafsiran Kiai Sholeh Darat. Dan bagaimana contoh-contoh yang terdapat dalam tafsir Faid al-Rahman.

\section{B. Sejarah Tafsir Al-Qur'an di Nusantara}

Penulisan tafsir al-Qur'an di Nusantara sudah terjadi sejak abad ke 16. Buktinya ditemukanya kitab Tafsir Surat al-Kahfi yang ditulis pada masa itu, akan tetapi belum diketahui siapa penulis kitab tersebut. ${ }^{5}$ Naskahnya dibawa oleh Erpinus (w. 1624) pada awal abad ke-17 M dari Aceh menuju Belanda, dan sekarang menjadi koleksi Cambridge University Library dengan katalog MS Ii.6.45. Naskah ini diduga ditulis pada masa awal pemerintahan Sultan Iskandar Muda (1607-1636), yang saat itu mufti kesultanan dipegang oleh Syams ad-

3 Islah Gusmian, Khazanah Tafsir Indonesia: Dari Hermeneutika hingga Ideologi, (LkiS: Yogyakarta, 2013). 53,

4 M. Quraish Shihab, Kidah Tafsir, (Tangerang: Lentera Hati, 2013), cet. 2, 369.

M. Nurdin Zuhdi, Pasaraya Tafsir al-Qur'an di Indonesia..., 61. 
Din as-Sumatrani, atau bahkan sebelumnya, yaitu Sultan Ala' ad-Din Ri'ayat Syah Sayyid al-Mukammil (1537-1604), yang saat itu mufti kesultanannya dipegang oleh Hamzah Fansuri. ${ }^{6}$ Karya tafsir ini belum diketahui siapa penulisnya dan kapan ditulis.

Satu abad kemudian, muncul Tafsir Tarjuman al-Mustafid yang ditulis oleh abd. al-Rauf al-Sinkili yang dikenal sebagai mufassir pertama di Indonesia yang telah menulis karya tafsir lengkap tiga puluh juz. Bisa dikatakan pertama, karena pada era sebelumnya belum ditemukan seorang mufassir dari Melayu-Indonesia yang mampu menulis lengkap tiga puluh juz. Karya ini pertama terbit di Istanbul (konstantinopel) pada tahun $1884 \mathrm{M}$. Lalu kemudian, kitab tersebut dicetak ulang berkali-kali di Istanbul, Makkah, Kairo, Bombay, Penang, Singapura setelah mendapatkan pengakuan dari para ulama Makkah dan Madinah. Terakhir karya ini diterbitkan di Indonesia pada tahun 1984. Bahwa Tafsir Tarjuman al-Mustafid ini diterbitkan di Timur tengah sudah berulang kali pada masa yang berbeda-beda. Maka menjadi cerminan karya tafsir yang bermutu dan bernilai tinggi juga sebagai tanda menunjukan tingginya intelektual penulisnya sendiri. Meski karya tafsir yang ditulis abd. al-Rauf al-Sinkili tidak diberikan angka tahun penyelesaianya, akan tetapi tidak ada keraguan jika beliau menulisnya ketika karirnya di Aceh. ${ }^{7}$ Pada abad ini muncul juga literatur tafsir bercorak sufistik yang ditulis di Sampon Aceh dengan judul Tasdiq al-Ma'arif, namun penulis dari tafsir ini tidak dapat ditemukan. Ditambah dari hasil penelitian Jons bahwa pada 1957 M telah ditemukan sekumpulan risalah tanpa nama pengarang yang memberi keterangan sangat berharga tentang sufisme Melayu abad ke-17. ${ }^{8}$ Tafsir ini yang merupakan tafsir sufistik dan ditulis untuk membela prinsip-prinsip ajaran sufi.

${ }^{6}$ Peter Riidle, Islam and The Malay-Indonesia World, Transmission and Responses, (Honolulu: University of Hawai'i Press, 2001), dalam Islah Gusmian, Bahasa dan Aksara Tafsir al-Qur'an di Indonesia, Jurnal Tsaqofah, Vol. 6, No. 1, April 2010, 5.

7 M. Nurdin Zuhdi, Pasaraya Tafsir al-Qur'an di Indonesia..., 62

${ }^{8}$ A.H. John, "Malay Sufism as Illustrated in an Anonymous collection of XVII th Century Tracts", JMBRAS, 1957, dalam Denys Lombard, Kerajaan Aceh: Zaman, h. 222. Dalam M. Nurdin Zuhdi, Pasaraya Tafsir al-Qur'an di Indonesia..., 64. 
Kemudian pada abad ke-19 muncul karya tafsir yang berjudul Kitab Fars 'idul Qur'an. Tafsir ini menggunakan bahasa Melayu-Jawi. Sebagaimana naskah Tafsir Surat al-Kahfi, penulisnya tidak dapat diketahui. Kitab tafsir ini ditulis dalam bentuk yang sangat sederhana, dan tampak seperti artikel tafsir, sebab hanya terdiri dari dua halaman dengan huruf kecil dan spasi rangkap. Literatur ini menafsirkan dua ayat dari surat al-Nisa', yaitu ayat 11 dan 12 yang berbicara mengenai warisan. Pada abad ini juga muncul sebuah literatur karya tafsir ut uh yang berjudul Tafsir Munir li Ma'alim al-Tanzil yang ditulis oleh ulama' asli Indonesia bernama Imam Muhammad Nawawi al-Bantani (1813-1879 M). Walaupun kitab ini ditulis oleh orang Indonesia, namun kitab ini ditulis menggunakan bahasa Arab. Penulisan tafsir ini dilakukan di Makkah dan selesai pada hari Rabu, 5 Rabiu'ul Akhir 1305 H. $^{9}$

Pada akhir abad ke-19 dan awal abad ke-20, banyak ulama' Indonesia yang menghasilkan karya tulis besar. Tidak sedikit dari karya-karya mereka yang ditulis menggunakan bahasa Arab. Setelah Kiai Ahmad Rifa'i dari kalisasak (1786-1875 M), yang banyak menulis kitab berbahasa Jawa. Pada Akhir abad ke-19, terdapat karya tafsir dengan menggunakan bahasa Jawa yaitu karya Kiai Sholeh Darat yang berjudul Faid al-Rahman Fi Tarjamah Tafsir Kalam Malik alDayyan. Beliau menulis kitab tafsir dengan lafadz pegon (huruf Arab berbahasa Jawa), yang menggunakan bahasa Jawa pesisiran atau diistilahkan sebagai Lughah al-Jawiyyah al-Merikiyyah (bahasa Jawa setempat). ${ }^{10}$ Kitab ini terdiri dari dua jilid dari surat al-Fatihah sampai surat an-Nisa'. Jilid pertama, terdiri dari surat al-Fatihah sampai surat al-Baqarah sebanyak 577 halaman. Sedang jilid yang kedua terdiri dari surat Ali 'Imran sampai surat an-Nisa' sebanyak 705 halaman. Kitab tafsir ini baru selesai sampai akhir surat an-Nisa'. ${ }^{11}$

Pada awal abad ke 20, romanisasi sudah meranjak ke semua sektor. Pemerintah Kolonial tersebut dapat dilihat adanya suatu sistem legislatif, seperti administrasi, kepegawaian, pendidikan dan lain-lain,

${ }^{9}$ Lihat Ibid..., M. Nurdin Zuhdi, Pasaraya Tafsir al-Qur'an di Indonesia..., h. 64 .

${ }^{10}$ Biografi KH. Sholeh Darat dalam Syarkh al-Hikam, Shahifa, 20016, xliii.

${ }^{11}$ M. Masrur, Kyai Sholeh Darat, Tafsir Faid al-Rahman..., 35. 
baik itu untuk pribumi maupun non-pribumi. ${ }^{12}$ Banyak kemungkinan pemakaian aksara roman telah memasuki ranah penulisan tafsir di Indonesia. Model penyajian tafsir yang berkonsentrasi pada suratsurat tertentu. Seperti pada penafsiran surat al-Fatihah, Lahir tafsir alQur'an al-Karim, Surat al-Fatihah karya Muhammad Nur Idri, pada tahun 1955. Kemudian lahir karya tafsir berjudul Rahasia Ummul Qur'an atau Surat al-Fatihah karya A. Bahry, pada tahun 1956. Ada juga yang khusus untuk surat Yasin misalnya, Tafsir Surah Yasien dengan Keterangan, pada tahun 1951, Tafsir al-Qur'an al-Karim karya Adnan Yahya Lubis, pada tahun 1978. Selain itu, pada abad ini terdapat karya tafsir yang khusus menafsirkan Juz-juz tertentu, seperti Juz Amma. Lahir karya dengan judul al-Burhan, Tafsir Juz Amma, ditulis oleh H. Abdulkarim, pada tahun 1992. ${ }^{13}$ Pada Abad ini juga ada karya tafsir yang lengkap 30 juz. Seperti, Tafsir al-Qur'an al-Karim bahasa Indonesia karya Mahmud Yunus, pada tahun 1938. Kemudian, dengan judul al-furqan Tafsir Qur'an. Tafsir ini ditulis dan diterbitkan secara berangsur-angsur, sampai selesai menjadi satu buku pada tahun 1950-an, ${ }^{14}$ dan masih banyak karya-karya lainya.

Sampai akhir adab ke-20, muncul beberapa karya tafsir yang sangat beragam dan kreatif. Serta muncul karya tafsir dengan berbagai metode dan pendekat an yang makin berkembang. Seperti Konsep Kufr dalam al-Qur'an Suatu Kajian Teologis dengan Pendekatan Tafsir Tematik, karya Harifuddin Cariwu. Kemudian, Konsep Perbuatan Manusia Menurut al-Qur'an, suatu Kajian Tafsir Tematik, karya oleh Jalaluddin Rahman. ${ }^{15}$ Kemudian tafsir-tafsir yang muncul abad ke 21, seperti Tafsir al-Misbah karya M.Quraish Shihab. Muncul karya tafsir berjudul al-Qur'an dan Tafsirnya, yang dikeluarkan oleh Pemerintahan Republik Indonesia melalui Kementrian Agama, dan Tafsir tematik yang dikeluarkan oleh Lajnah Pentasih Mushaf al-Qur'an Kementrian Agama RI. ${ }^{16}$ dan masih banyak karya-karya lainya dengan berbagai gaya trens penafsiran yang semakin berkembang.

\footnotetext{
${ }^{12}$ Islah Gusmian, Bahasa dan Aksara Tafsir al-Qur'an di Indonesia...., 6.

${ }^{13}$ Islah Gusmian, Khazanah Tafsir Indonesia: Dari Hermeneutika hingga Ideologi, (Yogyakarta: LkIs, 2013), 45-47.

${ }^{14}$ Islah Gusmian, Khazanah Tafsir Indonesia..., 48-49.

${ }^{15}$ Islah Gusmian, Khazanah Tafsir Indonesia..., 63-64.

${ }^{16}$ Islah Gusmian, Tafsir al-Qur'an di Indonesia: Sejarah dan Dinamika,
} 
Terbukti bahwa karya-karya al-Qur'an di Nusantara lahir dipengaruhi dari ruang sosial-budaya yang sangat beragam. Mulai sejak era Abd ar-Rauf as-Sinkili (1615-1693 M) pada abad 17 M hingga era M. Quraish Shihab pada era awal abad 21 M. Pada waktu rentang lebih abad itu, karya-karya tafsir al-Qur' an Nusant ara lahir dari tangan para intelektual Muslim dengan basis sosial yang beragam. Disamping itu, mereka juga memainkan peran sosial yang beragam, seperti sebagai penasihat pemerintahan (mufti),guru, atau kiai di pesantren, surau, atau madrasah. Peran-peran ini mencerminkan basis sosial dimana mereka mendedikasikan hidupnya untuk agama dan masyarakat. ${ }^{17}$

\section{Tipologi Tafsir Al-Qur'an di Nusantara}

Tipologi karya tafsir dalam tulisan ini berangkat dari pemetaan karya tafsir dengan menggunakan pandangan Sahiron Syamsuddin terbagi menjadi tiga, quasi obyektivis tradisionalis, quasi subjektivis, dan quasi obyektivis modernis. ${ }^{18}$ Ciri dari pandangan tipe obyektifis tradisionalis adalahpendekat ansuat upenafsiranyangtekstualdanhanya berkut at pada wilayah kebahasaan semata dan kurang memperhatikan pesan moral dibalik ayat yang ditafsirkanya. Sehingga hasil penafsiran hanya memperdebatkan wilayah gramatikal kebahasaan semata. Maka produk penafsiran seperti ini tidak bisa memecahkan problem-problem kekinian seperti contohnya kitab-kitab klasik. Produk tafsirannya seperti hal tersebut yang tidak bisa diharapkan akan mampu menjawab problematika kekinian yang tengah berkembang. Karena produk seperti ini yang tidak mampu mengungkap makna universal yang ada dibalik ayat yang ditafsirkan. Model penafsiran tersebut tidak memperhatikan kontekstualitas ayat yang ditafsirkan, akan tetapi lebih menekankan pada aspek lingustik atau lebih kepada tekstual semata. ${ }^{19}$

Sedangkan dalampandanganquasisubyektivis adalahpendekatan tafsir yang meninggalkan model-model tafsir klasik. Termasuk kategori mufassir modern yang menekankan dalam menafsirkan al-

Jurnal nun, Vol 1., 2015, 5.

17 Islah Gusmian, Tafsir al-Qur'an di Indonesia: Sejarah dan Dinamika, Jurnal Nun, Vol 1., 2015, 4

${ }^{18}$ M. Nurdin Zuhdi, Pasaraya Tafsir al-Qur'an di Indonesia..., 34.

${ }^{19}$ M. Nurdin Zuhdi, Pasaraya Tafsir al-Qur'an di Indonesia..., 35 
Qur'an sesuai dengan perkembangan ilmu modern, baik ilmu eksakta maupun non eksakta. Sedangkan di Indonesia sendiri belum ada yang berani melakukan penafsiran yang benar-benar meninggalkan metodologi klasik dan menggunakan murni metodologi kontemporer. Selain itu masih berhati-hati dengan perkembangan model penafsiran dengan metode kontemporer, maka wajar jika metode yang digunakan masih menggunakan metode klasik atau yang sudah ada dalam ulum al-Qur'an. ${ }^{20}$

Sedangkan dalamtipeyang ketiga adalah quasiobyektifis modern, ciri dari corak karya ini adalah penafsiran yang nuansanya masyarakat dan sosial. Suatu pemahaman al-Qur'an dengan menggunakan metode klasik yang telah ada seperti asbabun al-nuzul, nasikh dan mansukh, muhkam dan mutasabih dan lainnya dengan tanpa mengabaikan perangkat metode baru modern-kontemporer. Menurut Syahiron, pendekatan penafsiran ini memandang bahwa makna asal (bersifat historis) hanya sebagai pijakan awal bagi pembacaan al-Qur' an dimasa kini, makna asal literal tidak lagi dipandang sebagai pesan utama alQur'an. Jadi pandangan tersebut sama sekali tidak mengabaikan teks dan kontekstualitas al-Qur'an. Dengan menggunakan metodologi tersebut diharapkan bisa menjawab problem-problem kekinian. ${ }^{21}$

Sehingga, apabila dilihat dari segi tipologi tafsirnya, sebagaimana dijelaskan di atas, maka Tafsir faid al-Rahman ini masuk dalam tipologi yang ketiga, yaitu quasi objektivis modernis, karena disamping penafsiranya menggunakan dzahir dan isyary tapi tidak jauh dari teks ayatnya. Tafsir Faid al-Rahman tujuanya adalah untuk mencerdaskan anak bangsa sesuai sosio-kemasyarakatan pada waktu, yakni secara kontekstualisasi ayat al-Qur'an dijelaskan dalam penafsiranya. Didalam penafsiranya juga banyak mengutip kitabkitab klasik dan pendapat-pendapat ulama' khususnya ahli tasawuf, jadi masih sangat terasa penafsiran tasawufnya. Dan terkadang penafsiranya diambil dari makna aslinya dan historisitas ayat, serta dianalisis dengan pendapatnya. Selain itu, penafsiran yang dipaparkan di dalamnya juga ada yang mengenai tentang problem-problem sosial terkini yang masih membutuhkan solusi.

\footnotetext{
${ }^{20}$ M. Nurdin Zuhdi, Pasaraya Tafsir al-Qur'an di Indonesia..., 39

${ }^{21}$ M. Nurdin Zuhdi, Pasaraya Tafsir al-Qur'an di Indonesia..., 41
} 


\section{Biografi Kiai Sholeh Darat}

\section{Sejarah Hidup dan pendidikan Kiai Sholeh Darat}

Seorang ulama besar dari wilayah Jawa Tengah yang memiliki peran besar dalam penafsiran kitab salaf ke bahasa Jawa pada abad ke 19 adalah Muhammad Shaleh Ibn Umar al-Samarani, atau lebih dikenal dengan sebutan Kiai Shaleh Darat. ${ }^{22}$ Nama Darat digunakan untuk menyebutnya karena beliau mengabadikan di pesantren Darat, tepatnya didaerah Darat, semarang. Kiai Sholeh Darat dilahirkan di Desa Kedung Jumbleng, Kecamat an Mayong, Kabupaten Jepara, Jawa Tengah, sekitar tahun 1235 H/1820 M. Sedangkan informasi lainnya menyatakan bahwa kiai Sholeh lahir di Bangsri, Jepara. Beliau wafat di Semarang pada hari Jum'at Legi tanggal 28 Ramadhan 1321 H/18 Desember 1903 M. ${ }^{23}$

Kiai Sholeh Darat adalah putra Kiai 'Umar, salah seorang pejuang dalam perang Jawa (1825-1830) yang dilakukan oleh Pangeran Diponegoro melawan kolonial Belanda. ${ }^{24}$ Pendidikan beliau dimulai dari ayahnya sendiri yang meliputi ilmu dasar-dasar agama Islam, kemudian beliau belajar kepada Kyai Haji Syahid, ulama besar di Waturoyo, Pati, Jawa Tengah. ${ }^{25}$ Sesudah itu beliau dibawa ayahnya ke Semarang untuk belajar kepada beberapa ulama, diantaranya adalah Kyai Haji Muhammad Saleh Asnawi Kudus, Kyai Haji Ishaq

${ }^{22}$ Nama lengkap beliau adalah Muhammad Shalih bin Umar As-Samarani, yang dikenal dengan sebutan Mbah Soleh Darat. Ada dua alasan kenapa dipanggil dengan panggilan "kyai Sholeh Darat" pertama sesuai dengan akhir surat yang ia tujukan pada penghulu tafsir anom, penghulu kraton Surakarta yaitu: "al-Haqir Muhammad Shalih Darat" dan juga menulis nama "Muhammad Shalih bin Umar Darat Semarang" ketika menyebut nama-nama gurunya dalam kitab Mursyid alWajiz. Kedua, sebutan darat dibelakang namanya karena beliau tinggal disebuah daerah yang bernama Darat, yaitu suatu kawasan yang terletak dipesisir utara Semarang tempat mendarat orang-orang yang datang dari luar Jawa. Lihat dalam Ghazali Munir, Warisan Intelektual Islam Jawa: DalamPemikiran Kalam Muhammad Shalih al-Samarani, (Semarang: Walisongo Press, 2008), h. 35. Biografi KH. Sholeh Darat dalam Syarkh al-Hikam, Shahifa, 2016. xxv.

${ }^{23}$ A. Aziz Masyhuri, 99 Kiai Kharismatik Indonesia Biografi, Perjuangan, Ajaran, dan Doa-doa Utama yang Diwariskan, (Kutub:Yogyakarta, 2008), 66.

${ }^{24}$ Ghazali Munir, Warisan Intelektual Islam Jawa: Dalam Pemikiran Kalam Muhammad Shalih as-Samarani,(Walisongo Press:Semarang, 2008). 35

${ }^{25}$ Salah seorang cucu KH. Mutamamakkin dan kepada beliau KH. Sholeh Darat belajar beberapa kitab diantaranya Fath al-Qarib, Fath al-Mu'in, Minhaj alQawim, Syarh Khatib, dan Fath al-Wahhab. 
Damaran, Kyai Haji Abu Abdillah Muhammad Hadi Banguni (Mufti Semarang), Kyai Haji Ahmad Bafaqih Ba'alawi, dan Kyai Haji Abdul Ghani Bima. Ayahnya Kyai Umar sangat berharap agar anaknya kelak menjadi ulama yang berpengetahuan sekaligus ber-pengalaman, karena pengetahuan tanpa adanya pengalaman adalah kaku, sebaliknya berpengalaman tanpa pengetahuan yang cukup adalah ibarat tumbuhtumbuhan yang hidup di tanah yang gersang, karena seseorang yang mempunyai pengalaman dan pengetahuan yang banyaklah yang diperlukan oleh masyarakat Islam sepanjang zaman. Oleh hal itulah ayahnya mengajaknya merantau ke Singapura. ${ }^{26}$

Setelah menyelesaikan pendidikannya di Jawa, Kiai Sholeh Darat diajak ke Makkah oleh ayahnya dengan singgah beberapa saat di Singapura, dan di Makkah, ia belajar kepada beberapa orang ulama' masyhur seperti: 1. Syaikh Muhammad al-Muqri al-Misri al-Makki, kepadanya ia belajar ilmu 'aqa'id dengan kitab Umm al-Barahin karya Muhammad as-Sanusi. 2. Syaikh Muhammad ibn Sulaiman Hasb Allah pengajar di Masjid al-Haram dan Masjid an-Nabawi, kepadanya ia belajar Syarh al-Khatib, Fath al-Wahhab, dan Alfiyah ibn Malik beserta Syarah-nya, 3. Sayyid Muhammad ibn Zaini Dahlan, (12321304 H/1817- 1886 M), Mufti Syafi'iyyah di Makkah. Kepadanya ia belajar Ihya' 'Ulum ad-Din karya al-Ghazali, dan dari Sayyid Muhammad ibn Zaini Dahlan ia mendapatkan “ijazah”, 4. Al-“Alamah Ahmad an-Nahrawi al-Misri al-Makki, kepadanya belajar al-Hikam karya Ahmad ibn 'Ata' Allah. 5. Sayyid Muhammad Salih az-Zawawi al-Makki, pengajar di Masjid al-Haram, kepadanya ia belajar Ihya' Ulum ad-Din juz I dan II, dan lain-lain. ${ }^{27}$

Kiai Sholeh Darat ketika di makkah bertemu dengan Syekh Nawawi Banten dan Syekh Kholil Bin Abdul Latif Bangkalan Madura, lahir di Kedung Cemlung, Jepara pada tahun 1235 H./1820 M., dan wafat di Semarang pada hari Jum'at 29 Ramadhan $1321 \mathrm{H}$. atau 18 Desember 1903 M. Ketiga ulama yang berasal dari Jawa itu juga sezaman dan seperguruan di Mekah dengan beberapa ulama' dari

${ }^{26}$ Biografi KH. Sholeh Darat dalam Syarkh al-Hikam, Shahifa,2016. xxvii

${ }^{27}$ Ghazali Munir, Warisan Intelektual Islam Jawa....36 
Patani diantaranya adalah Syekh Muhammad Zain bin Mustafa AlFathani (Lahir 1233 H./1817 M., wafat 1325 H./1908 M.). ${ }^{28}$

Setelah beberapa tahun berkelana mencari ilmu, tibalah saatnya beliau diberikan izin untuk mengajar di Makkah, banyak muridnya yang berasal dari Tanah Jawa dan Melayu. Setelah menetap di Makkah selama beberapa tahun untuk belajar dan mengajar, Kiai Sholeh Darat terpanggil hatinya untuk pulang ke Semarang karena bertanggung jawab dan ingin ber-khidmat terhadap tanah tumpah darah sendiri. "Hubbul wathan min al-Iman" yang artinya cinta tanah air sebagian dari iman. Itulah yang menyebabkan beliau harus pulang ke Semarang. ${ }^{29}$ Kemudian Kiai Sholeh Darat diambil menantu oleh Kiai Murtada, teman seperjuangan Kiai 'Umar, ayah Kiai Sholeh Darat dalam perang Jawa, sebagai prajurit Diponegoro dan dijodohkan dengan Sofiyah. Sejak saat itulah Kiai Sholeh Darat menetap di Semarang dan masih melanjutkan menuntut ilmu lagi kepada beberapa orang 'ulama', serta mendirikan pondok pesantren yang semula tidak menggunakan nama. Namun, lambat laun terkenal dengan nama Pondok Pesantren Darat. ${ }^{30}$ Sebagaimana tradisi ulama dunia Melayu terutama ulama Jawa dan Patani pada zaman itu, bahwa setelah pulang dari Makkah harus mendirikan pusat pengajian berupa Pondok Pesantren. Seperti halnya Mbah Sholeh mendirikan pondok pesantren di pesisir kota Semarang. ${ }^{31}$

Diantara murid-murid beliau yang menjadi ulama' besar, ${ }^{32}$ antara lain:(1)Syaikh Mahfudz at-Tirmisi(1866-1919), terkenal Ulama'besar

\footnotetext{
${ }^{28}$ Biografi KH. Sholeh Darat dalam Syarkh al-Hikam, Shahifa, 2016. xxxi

${ }^{29}$ Biografi KH. Sholeh Darat dalam Syarkh al-Hikam, Shahifa, 20016 xxxixxxii

${ }^{30}$ M. Masrur, Kyai Sholeh Darat, Tafsir Faid al-Rahman dan RA. Kartini, jurnal At-Taqaddum, Vol. 4, No. 1, Juli 2012. 33

${ }^{31}$ Dalam beberapa versi disebutkan bahwa pesantren yang didirikan KH. Sholeh Darat bukan berarti pesantren yang sesungguhnya sebagaimana kebanyakan pesantren yang berdiri gedung-gedung sebagai tempat tidur para santri, akan tetapi pesantren disini hanyalah berupa majelis pengajian dengan kajian-kajian keIslaman yang diikuti oleh santri-santri kalong, lihat dalam KH.A.Aziz Masyhuri, 99 Kiai Kharismatik Indonesia, 77

${ }^{32}$ Diant ara murid beliau, tiga orang yang disahkan sebagai Pahlawan Nasional Indonesia, yaitu KH. Ahmad Dahlan (1868-1934 M.), dengan Surat Keputusan Pemerintah RI, No. 657, 27 Desember 1961, Hadratus Syekh Hasyim Asy’ari (1875-1947 M.), dengan Surat Keputusan Presi-den RI, No. 294, 17 November
} 
Madzhab Syafi'i, ahli bidang hadis, (2) K.H.Ahmad Dahlan (18681923), pendiri Muhammadiyah (3) K.H. Hasyim Asy'ari , (1871-1947), pendiri Nahdlatul 'Ulama, dan pondok pesantren Tebuireng Jombang, (4) K.H. Idris (w.1927 M) dari Solo yang membuka kembali pondok pesantren yang didirikan Kiai Jamsari, (5) K.H.Tahir, penerus pondok Pesantren Mangkang Wetan, Semarang (6) K.H. Dimyati (w.1934) dari Termas, pimpinan periode ke-3 Pondok Pesantren Termas, (7) KH.Khalil (w. 1940 M), pendiri pondok pesantren Rembang, (8) KH.Munawir (w.1940 M) pendiri pondok pesantren Krapyak Yogyakarta. (9) R.A Kartini, yang menjadi simbol kebanggaan kaum wanita Indonesia. ${ }^{33}$ Dengan demikian dapat dikatakan, Kiai Sholeh Darat merupakan seorang guru bagi ulama-ulama besar di Tanah Jawa.

\section{Perjumpaan R.A Kartini dengan Kiai Sholeh Darat}

Dari sekian banyak muridnya beliau, salah satu muridnya yang terkenal tetapi bukan dari kalangan kiai atau ulama' adalah Raden Ajeng Kartini. Karena RA Kartini inilah Kiai Shaleh Darat menjadi pelopor penerjemahan al-Qur'an ke Bahasa Jawa. Menurut catatan cucu Kiai Shaleh Darat yaitu dialog yang ditulis Nyonya Fadhila Shaleh, sebagai berikut: ${ }^{34}$

"Kiai, perkenankanlah saya menanyakan, bagaimana hukumnya apabilaseorang yang berilmu, namun menyembunyikanilmunya? «Tertegun Kiai Sholeh Darat mendengar pertanyaan Kartini yang diajukan secara diplomatis itu.»Mengapa Raden Ajeng bertanya demikian?». Kiai Shaleh Darat balik bertanya, sambil berpikir kalau saja apa yang dimaksud oleh pertanyaan Kartini pernah terlintas dalam pikirannya. «Kiai, selama hidupku baru kali inilah aku sempat mengerti makna dan arti surat pertama, dan induk Al-Quran yang isinya begitu indah menggetarkan sanubariku. Maka bukan buatan rasa syukur hati aku kepada Allah, namun aku heran tak habis-habisnya, mengapa selama

1964, Raden Ajeng Kartini (1879-1904 M.), dengan Surat Keputusan Presiden RI, No. 108, 12 Mei 1964.

${ }^{33}$ Mukhamad Shokheh,Tradisi Intelektual Ulama Jawa...., 162.

${ }^{34}$ M.Masrur,Kyai Sholeh Darat, Tafsir Faid al-Rahman...., 41. 
ini para ulama kita melarang keras penerjemahan dan penafsiran Al-Quran dalam bahasa Jawa. Bukankah Al-Quran itu justru kitab pimpinan hidup bahagia dan sejahtera bagi manusia?."

RA Kartini pernah punya pengalaman tidak menyenangkan saat mempelajari Islam. Guru ngajinya memarahinya karena dia bertanya mengenai arti sebuah ayat Qur'an. Kemudian ketika berkunjung ke rumah pamannya, seorang Bupati Demak, RA Kartini menyempatkan diri mengikuti pengajian yang disampaikan oleh Kiai Shaleh Darat. Saat itu beliau sedang mengajarkan tafsir Surat al-Fatihah. RAKartini menjadi amat tertarik dengan model pengajian yang disajikan oleh Kiai Shaleh Darat. Dalam sebuah pertemuan RA Kartini meminta agar Qur'an diterjemahkan karena menurutnya tidak ada gunanya membaca kitab suci yang tidak diketahui artinya. Tetapi pada waktu itu penjajah Belanda secara resmi melarang orang menerjemahkan alQur'an. Kemudian Kiai Shaleh Darat melanggar larangan ini. Beliau menerjemahkan Qur'an ditulis dalam huruf "arab gundul” (pegon) sehingga tidak dicurigai penjajah. Kitab tafsir dan terjemahan Qur'an ini diberi nama Kitab Faid al-Rahman, tafsir pertama di Nusantara dalam bahasa Jawa dengan aksara Arab. Kitab ini yang pernah dihadiahkannya kepada R.A. Kartini pada saat dia menikah dengan R.M. Joyodiningrat, seroang Bupati Rembang. ${ }^{35}$

\section{Karya-karya Kiai Sholeh Darat}

Dalam tradisi keilmuan Kiai Sholeh Darat tidak hanya menuangkan karyannya melalui lesan (oral tradition), ceramah dan pengajian saja. Akan tetapi beliau juga banyak melahirkan dalam segi karya tulis (written tradition). Secara keilmuanya, beliau dapat dinilai masuk sebagai ulama' yang produktif, terbukti banyak dari kitab-kitab yang ditulisnya dengan menggunakan bahasa Jawa (Arab pegon). Sampai saat ini karya-karyanya banyak diapakai dan dibaca di pesantren-pesantren di Jawa.

Diantara karya-karya Kiai Shaleh Darat yang menjadi hobi kreatifitasnya, antara lain: (1). Majmu'at Asy-Syari'at al-Kafiyah li al-

${ }^{35}$ A.Aziz Masyhuri, 99 Kiai Kharismatik Indonesia Biografi...h.78. Lihat juga M. Masrur, Kyai Sholeh Darat, Tafsir Faid al-Rahman dan RA. Kartini, jurnal At-Taqaddum, Vol. 4, No. 1, Juli 2012. 34. 
Awam. (2). Kitab Munjiyat, petikan penting dari kitab Ihya' Ulumuddin karya Al-Ghazali (3). Syarakh al-Hikam karya Syekh Ibnu Atho'ilah As-Sakandari. (4) Kitab Latha'if al-Thaharat. (5). Kitab Manasik AlHajj. (6). Pasolatan (7). Terjemahan Sabil Al- 'Abid 'Ala Jauharah AtTauhid.(8). Minhajal-Atqiya'.(9). Mursyid al-Wajiz. (10). Kitab Hadits Al-Mi'raj (11). Syarh al-Maulid al-Burdah (12). Kitab tafsir Faid alRahman.(13). Asrar As-Sholah.(14). Syarh Barzanji. ${ }^{36}$ Hampir semua karya Kiai Sholeh Darat ditulis dalam bahasa Jawa dan menggunakan bahasa Jawa (Arab Pegon) hanya sebagian kecil yang ditulis dalam bahasa Arab, bahkan sebagian orang berpendapat bahwa orang yang paling berjasa menghidupkan dan menyebarluaskan tulisan bahasa Jawa (Arab Pegon) adalah Kiai Sholeh Darat Semarang. ${ }^{37}$

\section{E. Sekilas tentang Tafsir Faid al-Rahman}

\section{Latar Belakang Penulisan Tafsir}

Penulisan tafsîr Faid al-Rahman dilatarbelakangi oleh keinginan Kiai Sholeh Darat untuk menerjemahkan al-Qur'an ke dalam bahasa Jawa sehingga orang-orang awam pada masa itu bisa mempelajari al-Qur'an, karena saat itu orang-orang banyak yang tidak bisa bahasa Arab. ${ }^{38}$ Dan juga sebagai jawaban dari kegelisahan R.A Kartini, pada waktu itu ${ }^{39}$ tidak ada ulama' yang berani menerjemahkan al-Qur'an dalam bahasa Jawa karena al-Qur'an dianggap terlalu suci, dan tidak boleh diterjemahkan ke dalam bahasa apapun dan melarang keras penerjemahan dan penafsiran al-Qur' an dalam bahasa Jawa.

Kitab tafsir karya Kiai Sholeh Darat diberi nama tafsir Faid alRahman Fi Tarjamat Kalam Malik ad-Dayyan. ${ }^{40}$ Judul faid al-Rahman

\footnotetext{
${ }^{36}$ Biografi KH. Sholeh Darat dalam Syarkh al-Hikam, Shahifa, 2016, xlv.

${ }^{37}$ Biografi KH. Sholeh Darat dalam Syarkh al-Hikam, Shahifa, 2016, xxxv - xliv.

${ }^{38}$ Dalam muqadimahnya menjelaskan: "Saya melihat pada umumnya orangorang awam tidak ada yang memperhatikan tentang maknanya al-Qur'an karena tidak tahu caranya dan tidak tahu maknanya karena al-Quran diturunkan dengan bahasa Arab, maka dari itu saya bermaksud membuat terjemahan arti al-Qur'an" Lihat Muqaddimah, Muhammad Shaleh ibnu Umar al-Samarani, Tafsir Faid alRahman fi Tarjamah Tafsir Kalam Malik ad-Dayyan, Juz 1.

${ }^{39} \mathrm{Pada}$ waktu itu masa penjajah Belanda karena secara resmi melarang keras orang-orang menerjemahkan al-Qüran.

${ }^{40}$ Disampaikan oleh Dr. KH. Inamuzzahidin dan KH. Imam Taufiq yang
} 
memperlihatkan bahwa kitab tafsir ini memiliki nuansa sufi (al-tafsir $f i$ al-lawn al-sufi). Secara bahasa, kata faid al-Rahman berarti limpahan dari Dzat yang maha kasih, sebagai isyarat bahwa kandungan tafsir tersebut merupakan emanasi atau limpahan kasih sayang Tuhan yang tercermin dalam uraian-uraian tafsirnya. ${ }^{41} \mathrm{Kitab}$ tersebut merupakan kitab tafsir al-Qur' an dengan menggunakan tulisan arab pegon dengan bahasa Jawa al-Maraki. ${ }^{42}$ Kiai Sholeh Darat menulis kitab tafsirnya belum sampai selesai, beliau hanya menyusun kitab tafsirnya terdiri dari dua jilid, mulai dari jilid 1, diawali dengan muqaddimah kitab Tafsir Faid al-Rahman, lalu dilanjutkan dengan muqaddimah Surat alFatihah, kemudian dilanjutkan dengan penafsiran ayat 1 sampai ayat 7. Kemudian dilanjutkan dengan tafsir Surat al-Baqarah yang dimulai dengan muqaddimah Surat al-Baqarah kemudian penafsiran ayat 1 sampai ayat 286. Dengan jumlah isinya 503 halaman. Jilid pertama ini mulai ditulis pada malam Kamis 20 Rajab 1309 H/19 Februari 1892 M, dan selesai pada malam Kamis 19 Jumad al-Awal 1310 H/9 Desember 1892 M. dicetak di Singapura oleh percetakan Haji Muhammad Amin pada tanggal 27 Rabi'ul Akhir 1311 H/7 November 1893 M. Jilid 2, Jilid Kedua, dimulai dari muqaddimah dari penulis kemudian muqaddimah surat Ali 'Imran dan dilanjutkan dengan penafsiran ayat 1 sampai ayat 200. Kemudian dilanjutkan dengan tafsir surat al-Nisa' yang dimulai dengan muqaddimah Surat al-Nisa' kemudian penafsiran ayat 1 sampai ayat 176. Dengan jumlah isinya 705 halaman. Jilid Kedua ini diselesaikannya pada hari Selasa tanggal 17 Safar 1312

sebagai narasumber atau mengisi pengajian mengenai corak tafsir faid al-Rahman. Waktu itu beliau menyimpulkan bahwa nama tafsir faid al-Rahman karena lebih bernuansa sosial dengan itu beliau memberi nama tafsir sosial karya Kiai Sholeh Darat. Beliau menjelaskan menggunakan powerpoint dengan membuat analisis triadik hermeneutika. Hadiri acara Kopisoda (komunitas pecinta Kiai Sholeh Darat) di Masjid Kauman Semarang. Pada Tanggal 19 April 2016.

${ }^{41}$ Abdul Mustaqim, Epistimologi Khazanah Tafsir Jawa: Studi Kritis atas Tafsir Faidl al-Rahman Karya Kiai Sholeh Darat, Ringkasan Riset Dosen UINSUKA, 2015/2016.

${ }^{42}$ Kata al-Maraki atau al-Meriki dalam cover beberapa karya KH.Sholeh Darat memunculkan beberapa pendapat, pertama kata al-Maraki merujuk sebuah daerah yaitu semarang dan sekitarnya, sedangkan yang kedua dibaca dengan sebutan al-Meriki yang dalam bahasa indonesia berarti "disini" sehingga memunculkan asumsi bahwa karya-karya dari KH.Sholeh Darat menggunakan bahasa dari daerah sini (kampung darat) 
H/20 Agustus 1894 M. dan dicetak oleh percetakan Haji Muhammad Amin pada tahun $1312 \mathrm{H} / 1895$ M. ${ }^{43}$

\section{Metode penyusunan dan Sumber Tafsir}

Dalam penyusunan kitab Tafsir Faid al-Rahman ini, Kiai Sholeh Darat mengawali dengan muqaddimah yang memuat latar belakang penulisan, sumber atau rujukan yang digunakan dalam melakukan penafsiran secara dzahir dan batin atau isyary. Dalam kitab Faid alRahman secara garis besar terdapat dua model penafsiran, pertama, penafsiran secara dzahir, yakni penafsiran ayat al-Qur'an dengan berdasarkan pada teks tersurat. Kedua, penafsiran secara batin atau isyari, yaitu penafsiran ayat-ayat al-Qur'an berdasarkan pada makna tersirat (makna batin). Dalam muqaddimahnya Kiai Sholeh Darat melarang mufassir untuk melakukan penafsiran secara batin atau isyary sebelum terlebih dahulu menafsirkan ayat secara $d z a h i r$. Adapun penulisan tafsir Faid al-Rahman mengikuti urutan mushaf (tartib mushafi) senantiasa dimulai dengan penjelsan at as identitas surat, yang termasuk didalamnya sejarah turun (asbabun nuzul), tempat turun, dan jumlah ayat. Diterangkan juga perbedaan ulama' tentang jumlah ayat dalam satu surat dan juga beliau menguraikan faidah-faidah yang terkandung dalam surat tersebut.

Adapun contoh penafsiran Kiai Sholeh Darat dalam tafsir Faid al-Rahman pada surat al-Baqarah: Tegese utawi iki surat alBaqarah iku ana ing Madinah tumurune, ayate rungatus wolung puluh pitu utawi nem sebab ikhtilafe waqof, utawi anggarane Madinah utawi Makkah iku endi-endi surat ingkang tumurune ba'da hijrah Madinah sanajan tumurune ing Makkah utawi a'rafah utawi tubu', utawi ayat tumurun qobla hijrah aku iku Makkah sanajan tumurun ora ana ing Makkah. Utawi iki Surat al-Baqarah iku awal-awale tumurune ayat-ayat ba'da hijrah. Utawi iki surat al-Baqarah iku ana pirang-pirang fadahe, lamun wanaja aghlam oumuhu maka ora bisa mlebu syaiton telung dina lan batal fangkawine wongkang ahli sakhrah, ing jerone iki

${ }^{43}$ HM. Muchoyyar, KH. Muhammad Shaleh al-Samarani : Studi Tatsir Faid ar-Rahman, Disertasi, tidak diterbitkan,(Jogjakarta : IAIN Sunan kalijaga, 2000). h. 97-98. Dalam M.Masrur, Kyai Sholeh Darat, Tafsir Faid al-Rahman....,35. 
surat ana sewu amar, lan sewu nahi, lan sewu hukum, lan sewu khobar.

Terjemahnya: Surat al-Baqarah Madaniyyah tersusun atas dua ratus delapan puluh tujuh ayat. Surat al-Baqarah ini turun dimadinah, jumlah ayatnya ada 286 atau 287 berdasarkan perbedaan tanda berhenti (waqaf). Dinamakan surat Madaniyyah apabila surat tersebut turun setelah hijrah, walaupun turunnya dimakkah atau Arafah atau Tabuk. Sedangkan dinamakan Makiyyah apabila surat tersebut turun sebelum Hijrah, meskipun turunnya tidak di Mekkah. Surat al-Baqarah merupakah surat yang pertama kali turun setelah Hijrah. Dalam surat ini terdapat beberapa faedah, diantaranya: apabila dibaca dirumah, syetan tidak bisa masuk selama tiga hari serta dapat menggugurkan orang yang berbuat sihir. Dalam surat ini memuat seribu perint ah, seribu larangan, seribu hukum dan seribu berita. ${ }^{44}$

Penggunaan tulisan Arab pegon dalam tafsir Faid al-Rahman merupakan respon terhadap kondisi sosial-politik serta masyarakat pada masa itu, karena pada masa itu (kolonial belanda) pemerintah melarang dengan keras terhadap penulisan tafsir ataupun terjemah alQur'an. ${ }^{45}$ Namun dalam segi susunannya menyerupai dengan kitabkitab berbahasa arab pada umumnya. Kiai Sholeh Darat mengambil sumber-sumber rujukan kitab tafsirannya dari beberapa para penafsir yang handal. Sebagaimana Kiai Sholeh Darat telah menyebutkan beberapa sumber-sumber yang ia gunakan dalam menafsirkan alQur' an dalam muqaddimah kitab Tafsir Faid al-Rahman: ${ }^{46}$

.... Mongko arah mangkono dadi nejo ingsun gawe terjemahe maknane Qur' an sangking kang wus den 'ibarataken poro Ulama koyo kitabe Imam Jalal al-Mahalli lan Imam Jalal As-Suyuti, lan liyo-liyane koyo Tafsir Al-Kabir li Imam Ar-Rozi. Lan Lubabu

${ }^{44}$ Muhammad Shalih bin Umar al-Samarani, Faid al-Rahman...., 26-27.

${ }^{45}$ Biografi KH. Sholeh Darat dalam Syarkh al-Hikam, Shahifa,2016. Xxxix.

46 Diskusi tentang "epistimologi Tafsir Faid al-Rahman karya Kiai Shaleh Darat", dengan anak SQH-Non Reguler, nama Mochamad Tholib Khoiril Waro. Tanggal 3 April 2016. Lihat juga Makalah Mochamad Tholib Khoiril Waro, “epistimologi Tafsir Faid al-Rahman karya Kiai Shaleh Darat." 
al-Ta'wil li Imam al-Khozin, lan tafsir Al-Ghozali. Lan ora pisanpisan gawe tarjamah ingsun kelawan ijtihade ingsun dewe, balik nukil sangking tafsire poro ulama kang Mujtahidin kelawan asale tafsir kang dzohire, mongko nukil tafsir kelawan isyari saking Imam Ghazali. Mongko lamun ningali siro ya ikhwan ono ingkang salah atowo ora muwafaqoh suloyo poro ulama salaf mongko iku sangking salahe paham ingsun. Mongko yen muwafaqoh kalayan kalam Ulama, mongko iku saking kalamu al-a'immah....." ${ }^{47}$

Terjemahnya:.... Maka dari arah tersebut saya bermaksud unt uk membuat terjemah makna al-Qur'an dari karya para ulama', seperti kitabnya imam Jalaluddin al-Mahalli dan Jalaludin alSuyuthi (Tafsir Jalalain), Tafsir al-Kabir karya Imam al-Razi, Lubab al-Ta'wil karya Imam al-Khazin, Tafsir al-Ghazali, dan tidak sekalipun saya menulis terjemah al-Qur'an dengan ijtihat sendiri, melainkan menyandarkan pada kitab tafsirnya para ulama yang ahli Ijtihad (Mujtahid) dengan asli Tafsir zahirnya, kemudian menukil tafsir dengan makna Isyari dari Imam al-Ghazali. Andaikan jika kalian melihat kesalahan atau ketidaksesuaian dengan para ulama hal tersebut dikarenakan kesalahan saya, dan jika kalian melihat kebenaran dan kesesuaian maka hal tersebut datangnya dari para ulama...

Kiai Sholeh Darat menjelaskan sumber-sumber penafsiran terkadang dengan sekilas mengkaitkan ayat al-Qur'an, Hadis, Akal, kitab-kitab tafsir klasik, dan beberapa pemikiran kaum sufi, yang ia gunakan sesuai dari aspek kandungan isinya.

1. Al-Qur'an

Kiai Sholeh Darat berdasarkan penafsirannya pada al-Qur'an. Pertama, bersumber dari pengakuan beliau dalam mudaqqimah kitabnya. Kedua, model penafsiran Kiai Shaleh Darat yang selalu mengaitkan dengan al-Qur'an, atau selalu mengembalikan penafsirannya pada al-Qur'an. Terkait penafsiran Kiai Sholeh Darat dalam QS. al-Fatihah: 6, ....Adapun yang disebut dengan hidayah

\footnotetext{
${ }^{47}$ Muhammad Shalih bin Umar al-Samarani, Tafsir Faid al-Rahman..., 1
} 
al-Kash yaitu hidayah yang diberikan kepada orang mu'min untuk menghantarkannya menuju jalannya surga sebagaimana firman Allah

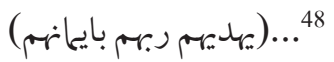

Selainayat tersebut,KiaiSholehDaratjugamengaitkanpenafsiran hudan lil muttaqin dalam QS.al-Baqarah: 2, dan QS.Qaf: 54, QS.alDzariyat: 55, sebagai berikut penjelasanya: "Kitab ini menjadi sebab yang dapat menunjukkan kepada semua manusia untuk bisa menjauhi syirik, maksiat serta menjalankan perintah dan meninggalkan sesuatu selain Allah dan hanya menghadap kepada Allah. Apabila manusia tersebut telah ditetapkan dizaman Azaliy, kelak pasti akan menjadi bahagia. Allah bersabda: (maka berilah peringatan dengan al-Qur'an kepada orang yang takut kepada janji-Ku), (sesungguhnya peringatan itu sangat bermanfaat bagi orang-orang yang beriman). " 49

\section{Al-Hadits}

Penafsiran Kiai Sholeh Darat yang merujuk pada hadis Nabi sangat banyak. Diantaranya ialah ketika beliau menafsirkan QS.AlFatihah: 6 tentang Maqam-maqam Hidayah yang beliau nukil dari alImam Ghazali. Adapaun redaksi tafsirnya ialah:

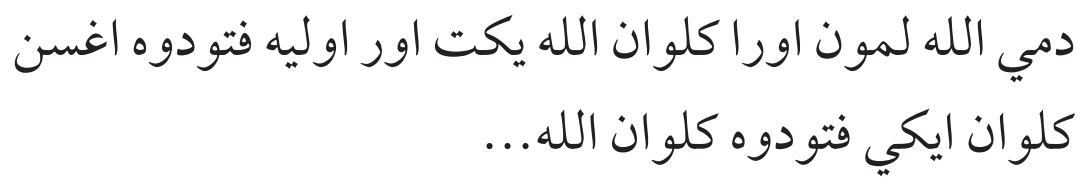

... Nabi telah bersabda "demi Allah jika bukan karena Allah sungguh saya tidak akan mendapatkan hidayah ini...”

Selain hadis di atas, penggunaan hadis sebagi sumber penafsiran oleh Kiai Sholeh Darat terlihat ketika menafsirkan QS. Al-Baqarah: 18 dengan mengutip sebuah hadis yang berbunyi: $:^{50}$

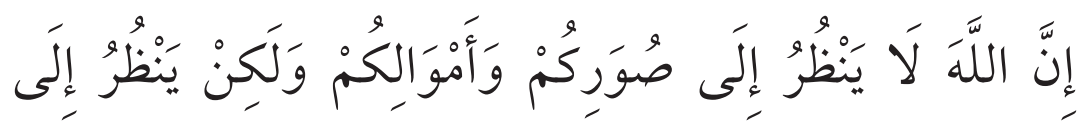

${ }^{48}$ Muhammad Shalih bin Umar al-Samarani, Tafsir Faid al-Rahman.... ,19.

49 Muhammad Shalih bin Umar al-Samarani, Tafsir Faid al-Rahman...., 2728.

${ }^{50}$ Muhammad Shalih bin Umar al-Samarani, Tafsir Faid al-Rahman..., 66. 


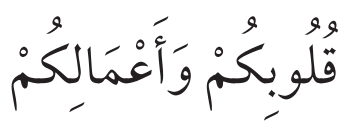

Hadits di atas merupakan hadis dari Imam Muslim riwayat Abu Hurairah dalam Shahih Muslim Kitab al-Birru wa al-Sillah wa al$A d a b$, adapun teks lengkap dari hadis di atas adalah sebagai berikut: ${ }^{51}$

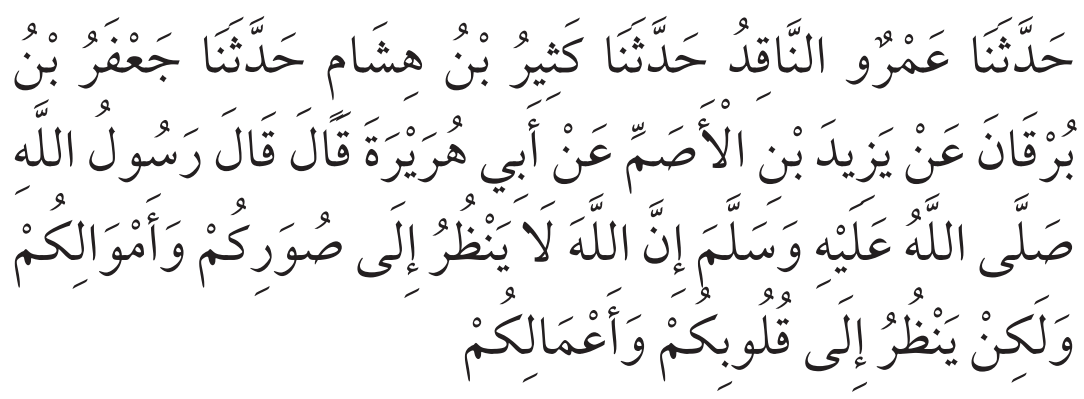

"sesungguhnya allah tidak melihat pada bentukmu dan hartamu akan tetapi Allah melihat pada hati dan perbuatanmu”.

\section{Akal}

Kiai Sholeh Darat tidak serta-merta dalam menafsirkan alQur'an dengan pribadinya sendiri. Penegasan ini sudah tertulis dalam muqaddimah tafsirnya bahwa akan menghindari penafsiran terhadap ijtihadnya sendiri. Menurut Kiai Sholeh Darat akal merupakan karunia dari tuhan yang maha kuasa yang harus digunakan untuk mengetahui keagungan-Nya, akal juga harus digunakan untuk dapat menjalankan syariat Agama, oleh karena itu peran akal dalam penafsiran-penafsiran beliau lebih pada pemanfaatan akal secara baik yang mengacu pada al-Qur' an dan Hadis.

\section{Kitab-Kitab Tafsir Klasik}

Dalam kutipan muqaddimah tafsirnya Kiai Sholeh Darat menyebutkan bahwa banyak menukil pendapat-pendapat dari para mufassir klasik seperti al-Razi dalam kitabnya Tafsir Mafatih al-Ghaib, Imam Jalaludin dalam kitabnya Tafsir al-Jalalain dan juga Imam alKhazin dalam kitabnya Lubab al-Ta'wil fi Ma'ani al-Tanzil. Diantara kitab tafsir yang juga sering menjadi rujukan Kiai Sholeh Darat ialah

${ }^{51}$ Imam Muslim, Shahih Muslim Kitab al-Birru wa al-Sillah wa al-Adab bab Tahrimu zulmi muslim, no. 4651 CD-Room Maktabah Syamilah. 
kitab tafsir Madarik al-Tanzil karya al-Nasafi dan Anwar al-Tanzil wa Asrar al-Ta'wil karya al-Baidhawi.

Salah satu contoh penafsiran Kiai Sholeh Darat yang merujuk pada ulama tafsir klasik ialah ketika beliau menafsirkan QS. AlBaqarah: 25. Sebagai berikut dijelaskan, Imam al-Nasafi berkata: ayat ini memberikan pengertian bahwa iman dan amal itu berbeda, atau tidak sama. Karena bersambungnya ('athaf) lafadz amanu dan 'amilu itu menunjukkan perbedaan, sebab setiap penyambung berbeda dengan yang disambung. Iman tidak akan sempurna tanpa amal, begitu pula sebaliknya. Sedangkan yang dimaksud dalam ayat ini adalah berkumpulnya iman dan amal dengan muthlak. Adapun iman tanpa amal, maka terhenti menunggu ampunan, apabila diampuni maka masuk surga, dan apabila tidak maka masuk neraka terlebih dahulu baru kemudian masuk surga. ${ }^{52}$

Kiai Sholeh Darat dalam kutipan tafsir diatas membedakan antara iman dan amal, akan tetapi amal itu merupakan penyempurna dari iman. Mengacu pada redaksi yang diucapkan oleh Kiai Shaleh Darat mengambil sumber dalam penafsiran ayat di atas dari imam al-Nasafi langsung, walaupun dalam muqoddimah beliau tidak mencantumkan nama al-Nasafi dan kitab tafsirnya.

\section{Kaum Sufi}

Salah satu sumber terpenting dalam kitab Faid al-Rahman karya Kiai Sholeh Darat ialah penukilan dari pendapat-pendapat Imam Sufi. Kiai Sholeh Darat mengatakan bahwa beliau menyandarkan penafsirannya dengan Imam al-Ghazali, namun dalam beberapa penafsiran beliau menyandarkan penafsirannya pada Ibnu 'Arabi.

Keterpengaruhan Kiai Sholeh Darat terhadap Imam al-Ghazali cukup besar, hal tersebut dapat dilihat kitab karya beliau yang berjudul Munjiyat Metik Saking Ihya' Ulum al-Din al-Ghazali (Munjiyat mengambil dari Ihya' Ulum al-Din al-Ghazali). Oleh karena itu, tidak menjadikan suatu hal yang mengherankan jika beliau banyak mengutip dan menyandarkan penafsirannya pada Imam al-Ghazali. ${ }^{53}$

\footnotetext{
${ }^{52}$ Muhammad Shalih bin Umar al-Samarani, Tafsir Faid al-Rahman..., 87.

${ }^{53}$ Contoh penafsiran Kiai Sholeh Darat terhadap QS. Al-Fatihah: 6. Dimana
} 
Ketika berbicara tentang keterkaitan Kiai Sholeh Darat dengan Ibn 'Arabi memang beliau tidak menulis sebuah kitab khusus yang berkaitan tentang Ibn 'Arabi, namun dalam beberapa penafsirannya Kiai Sholeh Darat merujuk pada beliau (Ibn 'Arabi). Adapun diantara penfasiran Kiai Sholeh Darat yang merujuk kepada Ibn 'Arabi ialah ketika beliau menafsirkan QS.Ali Imran: 19. Penjelasanya ketika... Syaikh al-Kabir Ibnu Arabi menjelaskan (Agama yang di ridhai Allah) Allah yang dimaksud disini ialah satu (tauhid) yang berkehendak dengan dirinya sendiri. Sedangkan yang dimaksud dengan agama ialah agama islam yang berarti ikhlas, seperti penyataan nabi Ibrahim (Saya mencari ridha Allah), artinya dengan keseluruhannya, melepaskan diri sehingga menyatu didalam-Nya... ${ }^{54}$

Dari konten penafsiranya dapat disimpulkan bahwa tafsir ini merupakan tafsir dengan menggunakan metode tahlili. Karena dapat dilihat dari penafsiran ayat yang dikaji secara mendalam dari berbagai aspek yang tercantum, seperti asbab nuzul, hadis, kitab-kitab tafsir klasik, pendapat ulama' khususnya tasawuf (kaum sufi) dan dikuatkan oleh dalil-dalil yang sesuai keilmuan.

\section{Contoh-contoh Tafsir Isyary dalam Penafsiran Kiai Sholeh Darat}

Menurut Thaher Ibn Asyur dalam tafsirnya mengemukakan, bahwa Tafsir isyary dapat dibenarkan selama isyarat-isyarat yang dikemukakan tidak keluar dari tiga macam isyarat. Pertama, suatu isyarat yang serupa keadaanya dengan apa yang dilukiskan ayat. $K e d u a$, isyarat yang lahir dari dorongan berprasangka baik dan optimisme, karena bisa jadi ada satu kalimat yang darinya terlintas satu makna, tapi bukan itu makna yang dimaksud oleh kalimat itu. Maka makna itu akan hadir ke benak karena dinilai penting dan selalu terlintas dalam benak sang mufassir. Ketiga, isyarat berupa hikmah dan pelajaran yang selalu ditarik oleh orang-orang yang selalu ingat, sadar dan menarik hikmah dari apa saja yang dihadapinya. Hal ini

beliau membagi tingkatan Hidayah menjadi tiga bagian yang merujuk pada pendapat Imam al-Ghazali dalam Ihya' Ulum al-Din. Empat tingkatan hidayah tersebut ialah yang pertama hidayah al-'am, kedua Hidayah al-Khash dan ketiga Hidayah alAkhash. Muhammad Shalih bin Umar al-Samarani, Tafsir Faid al-Rahman..., 19.

54 Muhammad Shalih bin Umar al-Samarani, Tafsir Faid al-Rahman...., 35. 
tentu lebih lagi dengan pengamal tasawuf ketika mereka membaca alQur'an dan merenungkan maknanya. ${ }^{55}$

Dalam berbagai tafsir ada unsur-unsur tertentu yang menjadi ciri khas seorang mufassir dalam menafsirkan ayat al-Qur'an. Ketika Kiai Sholeh Darat menafsirkan suatu ayat al-Qur'an ia menggunakan penafsiran Isyary dalam tafsir Faid al-Rahman yang dilatarbelakangi oleh keterpengaruhan Kiai Sholeh Darat (Mushonnif) sendiri terhadap tokoh-tokoh Tasawuf seperti Imam al-Ghazali dengan kitabnya Ihya' Ulumuddin dan Ibnu 'Athaillah dengan kitabnya Syarah Hikam. Keterpengaruhan tersebut dapat dibacamelalui karya-karyabeliauyang merespon terhadap kitab-kitab karya al-Ghazali dan Ibnu 'Athaillah diantaranya: kitab Al-Munjiyat, kitab Majmu'ah asy-Syari'ah li al'Awam yang dinukil dari kitab Ihya' 'Ulumuddin dan kitab Terjemah pegon kitab Syarah Hikam karya Ibnu 'Athaillah. ${ }^{56}$

Contoh-contoh tafsir isyary dalam penafsiran Kiai Sholeh Darat, antara lain akan dijelaskan sebagai berikut:

1. Kiai Sholeh Darat menjelaskan unsur-unsur isyary yang melekat pada lafadz dalam menafsirkan sebuah ayat al-Qur'an.

Secarasingkat, bahwabentukseorang muslimyangtidakmerusak bumi adalah mereka yang tidak melakukan perbuatan-perbuatan yang menimbulkan kufur, musyrik dan permusuhan antar sesama. Menurut Kiai Sholeh Darat rusaknya tubuh jasmani atau badan karena perbuatan-perbuat an maksiat dan rusaknya tubuh rohani akan menjadi seperti jiwanya orang mati karena mengikuti hawa nafsu yang tidak terkontrol. Dalam penafsiran Kiai Sholeh Darat sangat terasa dengan pengalaman kepribadianya yang memiliki banyak amalan-amalan dan jiwa tasawuf yang tinggi. Berikut contoh deskripsi dalam tafsir Faid al-Rahman, QS. Al-Baqarah: 11.

Makna isyary wal asrori setuhune pengucape mukminin“la tufsidu fi al-ardh" artine aja ono podo agamo siro kabeh kelawan

${ }^{55}$ M. Quraish Shihab, Kidah Tafsir..., 372.

56 KH. Shaleh Darat, Kitab Munjiyat, Semarang: Thaha Putra, 1422. Lihat juga KH. Shaleh Darat, Matan Hikam, Semarang: Thaha Putra, 1422. Dan lihat terjemah bahasa Indonesia, Biografi KH. Sholeh Darat dalam Syarkh al-Hikam, Shahifa, 2016. 
nyekti bumi badane iro kelawan ngelakoni maksiat lan serakah lan ngedawah marang mukmin kerono rusake badan jasamaniyah iku sebab maksiat semono ugo rusake jas'adiyah maka ngluru soko ruhaniyah iro maka dadi mati ruh iro miturut hawa nepsu niro. ${ }^{57}$

Terjemahannya: Makna Isyari dari ayat tersebut ialah "sesungguhnya ucapan orang-orang muslim tersebut meminta untuk tidak merusak bumi dengan dirinya, dengan kekufuran, kemusyrikan dan permusuhan dengan sesama orang Islam" karena rusaknya tubuh (badan jasmani) itu karena kemaksiatan dan karena rusaknya tubuh maka jiwa (badan ruhaniyah) juga akan ikut rusak yang menjadikan matinya ruh karena telah mengikuti hawa nafsu.

2. Kiai Sholeh Darat menjelaskan penafsiran isyary yang lebih melekat pada makna dalam ayat al-Qur'an.

Seperti ketika dalam menafsirkan "Barang siapa yang berpaling sesudah itu, maka mereka itulah orang-orang yang fasik". Kiai Sholeh Darat menjelaskan arti dari makna tersebut bahwa akan dijanjikan semua para Nabi jika mau beriman kepada Nabi Muhammad yang tidak membangkang, tapi jika ada yang membangkang tidak beriman kepada Nabi Muhammad, maka kalian semua termasuk yang orang kufur yang disebut fasiqun yang artinya keluar dari agama Allah dan tidak memiliki agama yang benar. Adapun sebagai contoh penafsiran dalam tafsir faid al-Rahman surat Ali Imran: 82 :

Makno isyary, setuhune Allah subhanahu wata'ala iku angutokaken ing dhuriyah adam a'laihi al-sholat wa al-salam sangkeng sulbi adam kaya dene olehe janjine Allah ing adam kelawan wahdaniyah Allah. Semonougo janjine ing poro ambiya' kelawan risalah Muhammad shallahu a'laihi wasallam. Maka podo olehe janjine antarane anbiya' kabeh lan antarane umate senajan pengendika waida ahdallah mitsaqan al-nabi iku khusus

${ }^{57}$ Muhammad Shalih bin Umar al-Samarani, Faid al-Rahman...., juz 1, 5354. 
anbiya' kerono ningali pengendika "faman tawalla ba' da dzalika faulaika humu al-fasiqun”, artine den janjine anbiya' kabeh ing yento ngimanaken siro kabeh ya anbiya' ing nabi Muhammad maka sopo wonge mingi iman kelawan Muhammad sawuse den janjine sangkeng poro ambiya' kabeh kapureh iman maka nuli ora iman maka utawi wongkang mengkono ugi fasiqun artine metu sangkeng den Allah lan ora duwe agama. ${ }^{58}$

Terjemahan: Makna Isyari, sesungguhnya Allah swt. itu menciptakan keluarga Nabi Adam as dari tulang rusuknya Adam, hal ini sesuai yang dijanjikan oleh Allah kepada Adam dengan sifat wahdaniyah- Nya, begitu juga dengan janjinya para Nabi dengan risalah yang dibawa oleh Nabi Muhammad SAW. maka antara para Nabi dan umatnya akan mendapatkan janji dari Allah walaupun firman "Dan (ingatlah), ketika Allah mengambil janji dari para Nabi" itu berlaku khusus untuk para Nabi disebabkan ada firman yang lain "Barang siapa yang berpaling sesudah itu, maka mereka itulah orang-orang yang fasik" artinya dijanjikan kalian semua (para Nabi) jika kalian semua beriman kepada Nabi Muhammad. Maka barang siapa berpaling dari iman kepada Muhammad sesudah dijanjikan dari para Nabi, maka kalian akan jadi kufur kemudian tidak beriman, maka orang itu disebut Fasiqun artinya keluar dari agamanya Allah dan tidak mempunyai agama.

3. Kiai Sholeh Darat dalam menjelaskan penafsiran isyary lebih mengingatkan dengan sentuhan hati.

Ketika penafsiran isyary dijelaskan bahwa melaksanakan sholat dan zakat tidak perlu menganggu atau mengusik orang lain. Bahwa seorang mukmin harus mempunyai atau bekal amal bagus sebelum ia meninggal dunia, seperti melaksanakan sholat, zakat, silaturrahmi, shodaqoh dan amal-amal baik yang lainya. Kiai Sholeh Darat menjelaskan dengan sebuah nasehat seseorang yang diberikan Hidayah oleh Allah, maka seseorang akan sendirinya melaksanakan sholat dan

${ }^{58}$ Muhammad Shaleh ibnu Umar al-Samarani, Tafsir Faid al-Rahman.... Juz 2,136 . 
zakat sesuai dengan aturan Allah di alam Azal, ketika seseorang sudah dialam syahadah maka orang tersebut akan melaksanakan sholat dan zakat yang sesuai aturan Allah dengan begitu amaliyah atau qolbiyah akan seseorang lakukan sesuai dengan perintah Allah di alam azal kelak. Sebagai contohnya dalam tafsirfaid al-Rahman QS. al-Baqarah: 110:

Makna isyary, setuhune wong kang wes den paringi isyary taufiqe keparingan hidayah gelem sholat ingdalem azal maka nalikane wujud ingdalem alam syahadah ugo gelem sholat kelawan cocoke ilmu Allah fi al-zal, utawi endi-endi amal utawa endi-endi tho'at badaniyah utawa qalbiyah utawa maleh kang wes den ngelmuni fi al-azal bakal dilakoni ing dalem ngamal syahadah utawi nemu siro kabeh ing iku amal opo qodare yahudi ora luweh ora kurang, betapa Allah amberikan pula, ikulah artine ayat kana zalika fi al-kitab ora ina taufiq ilaihi fi alam Allah alAzal lan nur mertelaaken subhanahu wata'ala ing hale yahudi lan nasroni faqala ta'ala. ${ }^{59}$

Terjemahan: Makna Isyari, sesungguhnya seorang mukmin harus senantiasa melaksanakan perintah shalat dan zakat, janganlah mengusik(ibadah)oranglain. Karenaseorangmukminseharusnya mempunyai amal bagus sebelum dia meninggal dunia, yaitu dengan melaksanakan shalat, zakat, silaturrahmi, shodaqah dan amal-amal bagus lainya. Sesungguhnya seseorang yang sudah diberi hidayah oleh Allah akan senantiasa melaksanakan shalat dan zakat sesuai yang diajarkan oleh Allah dialam azal. Maka ketika dia sudah berada di alam syahadah, dia akan senantiasa melaksanakan shalat dan zakat sesuai dengan apa yang diajarkan oleh Allah. Dengan begitu amaliyah yang sifatnya badaniyah atau qalbiyah akan dia lakukan sesuai perintah Allah ketika di alam azal.

${ }^{59}$ Muhammad Shaleh ibnu Umar al-Samarani, Tafsir Faid al-Rahman.... Juz 1,228 . 
4. Kiai Sholeh Darat dalam menjelaskan penafsiran isyari berupa petunjuk.

Makna isyari, ketika menafsirkan bahwa, Allah swt itu Maha Suci yang jauh dari arah Kiblat. Diantara arah Barat dan Timur, kecuali hanya Allah yang mengetahui. Karena tidak ada usaha menghadap jasmani atau badan secara langsung bertatap muka dengan Allah. Tapi dengan usahanya masing-masing kepada hati diri-sendiri, itulah termasuk sudah dekat dengan Allah. Kiai Sholeh Darat menjelaskan bahwa setiap hati itu mempunyai qiblat masing-masing. Maka setiap hati itu menghadap, berarti sudah termasuk menghadap kepada Allah. Kemudian setiap ada musuh yang dihadapkan, maka kamu dan hanya Allah yang mempunyai qiblat jasmaniyah serta kaum yang mempunyai qiblat dzahir. Dan qiblat hati merupakan hanya kepada Allah yang bisa disembah. Sebagai contohnya dalam tafsir faid al-Rahman Surat alBaqarah: 115.

Artine wajeb bagi semua mukmin mitirut Allah swt. Makna isyari, setuhune Allah swt iku maha suci adoh sangkeng jahan (arah) kabeh. Al-masyriq wa al-magrib kelawan dan nisbataken mareng khusus Allah iku diweruhi. Kerono ora ono ingkang den ikhtiyar iku kok madepe rupo jasmani mareng kiblat jasmani kaya gusti Allah mengkono ora. Ora angeng ingkang den ikhtiyar madepe ati kelawan ingsun den podo parek Allah swt kerono saben-saben ati iku nduweni qiblat dewe-dewe maha mulyo. Maka tatkalane wes hasel madepe ati marang Allah kelawan mengkono sangkeng saben-saben masuh mongko endi-endi barang kang siro depaken mengkono ingatase kuno siro namung Allah swt kelawan qiblat jasmaniyah serta kelawan ingsun kang qoum mareng qiblat dzohir. Lan qiblat al-qalb mareng Allah kelawan barang den sembah Allah swt. ${ }^{60}$

Dalam perkembangan penafsiran isyari tersebut, bisa ditemukan kesan yang diperoleh dari pengamatan dan pembacaan ayat-ayat alQur' an tidak hanya terbatas pada kaum sufi saja. Bisa terjadi dari pembacaan terhadap ayat-ayat al-Qur'an, seorang peneliti yang tulus

${ }^{60}$ Muhammad Shaleh ibnu Umar al-Samarani, Tafsir Faid al-Rahman.... Juz 1,235 . 
dapat menemukan isyarat-isyarat dari ayat-ayat al-Qur'an yang tidak secara langsung ditegaskan oleh al-Qur'an, tetapi dari kesan yang ditimbulkan oleh redaksinya, atau jumlah pengulanganya.

Dalam penelitian unsur-unsur bernuansa isyari yang nampak dalam tafsir faid al-Rahman, bahwa tidak semua Kiai Sholeh Darat menafsirkan dengan makna Isyari, tapi ketika ia menafsirkan makna isyari dengan mengungkapkan pengalamanya yang berkaitan dengan kesucianya dan batinya yang bersifat nasehat atau memberikan petunjuk ketika berhubungan dengan kultur sosial dan masyarakat setempat.

\section{E. Kesimpulan}

Masing-masing mufassir mempunyai karakteristik dalam menafsirkan sebuah ayat-ayat al-Qur'an sesuai dengan sosio-kultural dan intelektual mufassirnya. Penafsiran beliau dilatarbelakangi oleh keterpengaruhan Kiai Sholeh Darat sendiri terhadap tokoh-tokoh Tasawuf seperti Imam al-Ghazali dan Ibnu 'Athaillah dengan melihat karya-karya kitab yang ditulis. Termasuk Tafsir Faid al-Rahman karya Kiai Sholeh Darat ini memiliki penafsiran yang nampak sangat khas yaitu dengan penafsiran bernuansa isyary. Adapun contoh-contoh penafsiran yang ditampilkan nampak ada unsur-unsur penafsiran isyary yang lebih melekat dengan sosio-kultural, serta kontribusinya memberikan corak tafsir dan memberikan solusi problem sosial di Nusantara. 


\section{Daftar Pustaka}

M. Masrur, Kyai Sholeh Darat, Tafsir Faid al-Rahman dan RA. Kartini, jurnal At-Taqaddum, Vol. 4, No. 1, Juli 2012.

Muhammad Nur Kholis Setiawan, Tafsir al-Qur'an dalam konteks keIndonesiaan dengan pola pendekatan Tematik Kombinatif, Buku Pidato pengukuhan Guru Besar UIN-Suka 2012.

Islah Gusmian, Khazanah Tafsir Indonesia: Dari Hermeneutika hingga Ideologi, (LkiS: Yogyakarta, 2013).

M. Quraish Shihab, Kidah Tafsir, (Tangerang: Lentera Hati, 2013), cet. 2.

Ghazali Munir, Warisan Intelektual Islam Jawa: DalamPemikiran Kalam Muhammad Shalih al-Samarani, (Semarang: Walisongo Press, 2008).

Biografi KH. Sholeh Darat dalam Syarkh al-Hikam, Shahifa, 2016.

A. Aziz Masyhuri, 99 Kiai Kharismatik Indonesia Biografi, Perjuangan, Ajaran, dan Doa-doa Utama yang Diwariskan, (Kutub:Yogyakarta, 2008).

Ghazali Munir, Warisan Intelektual Islam Jawa: Dalam Pemikiran Kalam Muhammad Shalih as-Samarani,(Walisongo Press:Semarang, 2008).

Salah seorang cucu KH. Mutamamakkin dan kepada beliau KH. Sholeh Darat belajar beberapa kitab diantaranya Fath al-Qarib, Fath al-Mu'in, Minhaj al-Qawim, Syarh Khatib, dan Fath alWahhab. Biografi KH. Sholeh Darat dalam Syarkh al-Hikam, Shahifa,2016.

M. Masrur, Kyai Sholeh Darat, Tafsir Faid al-Rahman dan RA. Kartini, jurnal At-Taqaddum, Vol. 4, No. 1, Juli 2012.

Biografi KH. Sholeh Darat dalam Syarkh al-Hikam, Shahifa, 2016.

Peter Riidle, Islam and The Malay-Indonesia World, Transmission and Responses, (Honolulu: University of Hawai'i Press, 2001), dalam Islah Gusmian, Bahasa dan Aksara Tafsir al-Qur' an di Indonesia, Jurnal Tsaqofah, Vol. 6, No. 1, April 2010. 
A.H. John, "Malay Sufism as Illustrated in an Anonymous collection of XVII th Century Tracts", JMBRAS, 1957, dalam Denys Lombard, Kerajaan Aceh: Zaman, h. 222. Dalam M. Nurdin Zuhdi, Pasaraya Tafsir al-Qur'an di Indonesia....

Islah Gusmian, Khazanah Tafsir Indonesia: Dari Hermeneutika hingga Ideologi, (Yogyakarta: LkIs, 2013)

Muhammad Shaleh ibnu Umar al-Samarani, Tafsir Faid al-Rahman $f i$ Tarjamah Tafsir Kalam Malik ad-Dayyan, Juz 1.

HM. Muchoyyar, KH. Muhammad Shaleh al-Samarani : Studi Tatsir Faid ar-Rahman,Disertasi, tidak diterbitkan,(Jogjakarta: IAIN Sunan kalijaga, 2000).

Diskusi tentang "epistimologi Tafsir Faid al-Rahman karya Kiai Shaleh Darat", dengan anak SQH-Non Reguler, nama Mochamad Tholib Khoiril Waro. Tanggal 3 April 2016. Lihat juga Makalah Mochamad Tholib Khoiril Waro, "epistimologi Tafsir Faid alRahman karya Kiai Shaleh Darat."

Imam Muslim, Shahih Muslim Kitab al-Birru wa al-Sillah wa al-Adab bab Tahrimu zulmi muslim, no. 4651 CD-Room Maktabah Syamilah.

KH. Shaleh Darat, Kitab Munjiyat, Semarang: Thaha Putra, 1422.

Abdul Mustaqim, Epistimologi Khazanah Tafsir Jawa: Studi Kritis atas Tafsir Faidl al-Rahman Karya Kiai Sholeh Darat, Ringkasan Riset (Belum dipublikasikan: UIN-SUKA, 2016) 